Zhandossova Zh.Zh., Tatarinov D.V.

Issues of regulating customs tariffs in EAEU due to the membership of the Republic of Kazakhstan to the WTO

Жандосова Ж.Ж., Татаринов А.B.

Қазақстан Республикасының АСҰ-ға мүше болуына байланысты ЕАЭО кеден тарифтерін реттеу бойынша сұрақтары

Жандосова Ж.Ж., Татаринов А.B.

Вопросы по регулированию таможенных тарифов в ЕАЭС в связи с членством Республики Казахстан в ВТО
Republic of Kazakhstan is a member of international organizations. One of the most important strategic objectives of the external economic policy of the Republic of Kazakhstan is the promotion of the state in the international integration process. Kazakhstan's accession to the WTO ensures the fair treatment of our exports on the markets of other countries and at the same time obliges to provide the same conditions for the import of foreign goods and services in our home market. In this context, Kazakhstan has become a full member of the World Trade Organization in 2015. This article is considered the mechanisms of regulation of customs tariffs in the EAEU due to the membership of the Republic of Kazakhstan to the WTO, as well as ways to minimize the risks of non-compliance of customs duties of EAEU `s member countries.

Key words: law, unification, legislation, integration, EAEU, WTO, customs regime, duty.

Қазақстан Республикасы көптеген халықаралық ұйымдардың мүшесі болып табылады. Еліміздің сыртқы экономикалық саясатының маңызды стратегиялық мақсаттарының бірі мемлекеттің халықаралық интеграциялық үлерістерге белсенді қатысуы болып табылады. Осыған орай, 2015 жылы Қазақстан Аүниежүзілік сауда ұйымының толыққанды мүшесі болды. Қазақстанның АСҰ-ға мүше болуы басқа елдер нарығында біздің экспортқа қатысты әділ көзқарасқа кепілАік береді, сонымен қатар, сондай жағдайларды шет елдік тауарлар мен қызметтерге біздің нарығымызда қамтамасыз етуге міндеттейАі. Бұл мақалада Қазақстан Республикасының АСҰ-ға мүше болуына байланысты ЕАЭО кеден тарифтерін реттеудің халықаралық және ішкі құқықтық тетіктері, сондай-ақ ЕАЭО мүше-мемлекеттері кедендік баждарының сәйкессіздік қауіптерін төмендетудің әдістері қарастырылады.

Түйін сөздер: құқық, унификация, заңнама, интеграция, ЕАЭО, $\Delta C Ұ$, кедендік режим, баж.

Республика Казахстан является членом многих международных организаций. ОАной из важнейших стратегических целей внешнеэкономической политики страны является продвижение государства в международные интеграционные процессы. В этой связи Казахстан ста^ полноправным членом Всемирной торговой организации в 2015 году. Вступление Казахстана в ВТО гарантирует справедливое отношение к нашему экспорту на рынках других стран, и в то же время обязывает обеспечивать такие же условия Аля импорта иностранных товаров и услуг на наш внутренний рынок. В Аанной статье рассматриваются международные и внутренние правовые механизмы по регулированию таможенных тарифов в ЕАЭС в связи с членством Республики Казахстан в ВТО, а также способы минимизирования рисков несоответствия таможенных пошлин странов-членов ЕАЭС.

Кмючевые слова: право, унификация, законодательство, интеграция, ЕАЭС, ВТО, таможенный режим, пошлина. 


\section{ISSUES OF REGULATING CUSTOMS TARIFFS IN EAEU DUE TO THE MEMBERSHIP OF THE REPUBLIC OF KAZAKHSTAN TO THE WTO}

The Republic of Kazakhstan has become a full member of the World Trade Organization (hereinafter - the «WTO»). This event is very important for our country in the field of international trade. Membership in the WTO will enable Kazakhstan to export goods to the markets of other members of WTO on the transport rates, which are used in transporting goods within these countries. To date, more than $50 \%$ of Kazakhstan's trade turnover accounts for the WTO's member states, and therefore it is very important for Kazakhstan to trade with its major trading partners in the framework of a common legal space.

Also, accession to the WTO enables:

1) realization of their current and strategic trade and economic interests through effective participation in multilateral trade negotiations in the development of new international trade rules;

2) improving the domestic legislation in line with WTO rules;

3) creating more jobs and improving the welfare of the population by capital inflows into the country, in particular in the form of foreign direct investment;

4) the elimination of trade restrictions policies [1, p. 87-89.].

At the same time there is the risk of increased competition for domestic producers.

Accession to the WTO initiated a change of the current legislation of the Republic of Kazakhstan in accordance with the commitments made by the Republic of Kazakhstan in the framework of accession to the WTO. To this end, the Ministry of National Economy of the Republic of Kazakhstan has developed a draft of Law of the Republic of Kazakhstan «On amendments and additions to some legislative acts in connection with the entry into the WTO», which came into force on 8 November, 2015.

But there was a significant problem, which was the subject of many years of negotiations between the representatives of our country, the Eurasian Economic Union (hereinafter - «EAEU») and the WTO.

Negotiations on the accession of the Republic of Kazakhstan to the World Trade Organization took place in four main areas:

- Bilateral negotiations on market access for goods;

- Bilateral negotiations on access to the services market;

- Multilateral negotiations on systemic issues; 
- Multilateral negotiations on agriculture.

For many commodity items import duties for Kazakhstan were significantly lower than the Common Customs Tariff of EAEU. After the WTO accession average rate of Kazakhstan decreased from 10.4 to $6.5 \%$. Goods and services from third countries may go to the market EAEU with low tariff rates through Kazakhstan. Since Kazakhstan has undertaken a lot of obligations to regulate tariff rates and customs activities based on the Report of the working group on the accession of the Republic of Kazakhstan to the WTO (hereinafter - «Report»).

The foregoing Report was prepared in 2015. It consists of 1175 points and 24 applications. It reveals a detailed description of the economic policy of the Republic of Kazakhstan, which is based on domestic regulations and international treaties to which the Republic of Kazakhstan has committed to comply. Also, the Working group reviewed the economic policies and foreign trade regime of Kazakhstan and the possible conditions of accession in the draft Protocol.

The most important point in this Report is the paragraph 1175, which includes the Republic of Kazakhstan's obligations in respect of certain specific issues. These issues relate to the following commitments for the following items:

1) restrictions on foreign exchange transactions or payments in foreign currencies will be used in accordance with the requirements of the WTO;

2) provision of legal entities with foreign investment in Kazakhstan, producing crude oil and natural gas, non-discriminatory access to pipelinesin accordance with national legislation of Kazakhstan;

3 ) ensuring the transparency of the privatization process and providing WTO's members with an annual report on the development of the privatization process for the continuation of the process;

4) providing enterprises of other WTO's members adequate in accordance with normal business practice opportunity to compete for participation in public procurement and sales;

5 ) the implementation of regulation of prices for goods and services contained in Annex 4;

6) uniform application of the provisions of the WTO Agreement on the entire territory of the Republic of Kazakhstan, including the regions involved in cross-border trade, special economic zones and other areas where special regimes for tariffs, taxes and regulations can be established;

7) the inclusion in the decision of the $\mathrm{CU}$ Commission dated 18 June, 2010 № 308 «On the Rules of Procedure to make proposals on measures to regulate foreign trade in the Customs Union
Commission» mechanism of the prior publication of the proposed draft of normative acts of the EAEU, till their adoption, as well as granting to the memberstates and interested parties a reasonable time to provide their views to the competent authority of the EAEU;

8) the preservation of the policy of accelerated registration procedure and the application of transparent and predictable requirements, not onerous to perform in respect of measures, affecting trade in goods with other WTO members;

9) conformity of all laws, regulations and other measures affecting imports and exports of goods with the relevant provisions of the WTO agreements, including the WTO Agreement on Import Licensing Procedures, and Articles I, III, VIII and XI of the WTO General Agreement on Tariffs and Trade from 1994 (hereinafter - «GATT»);

10) to join the Information Technology Agreement (ITA);

11) implementation of the commitments contained in the Schedule of accession, in particular through appropriate tools of EAEU, including the preservation of exemptions from the Common Customs Tariff of EAEU (hereinafter - «CCT

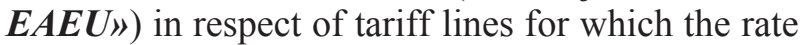
of EAEU duties do not correspond to the Schedule on joining, as long as the adjusted rates of duty, the negotiated and agreed in accordance with paragraphs 308-311, not be bound in the modified list of Kazakhstan and implemented by the EAEU;

12) not earlier than three years and six months from the date of full implementation of all final bound rates of duties contained in the Schedule of accession on goods Kazakhstan will seek to align the Schedule on joining with the final bound rate of Russian Federation's duties set out in its Protocol of Accession;

13) Kazakhstan's participation in the negotiations on compensation adjustment duties;

14) any fees and charges for rendered services, installed on or in connection with importation and exportation of goods, including those listed in paragraph 353 and Annex 13 of this Report or introduced in the future, will be applied in accordance with the relevant provisions of the Agreement of the WTO, in particular articles VIII and X of the GATT;

15) bringing the benefits of VAT for agricultural producers and processors in accordance with the rules of the WTO before 1 January 2018;

16) cancellation and non application by the Republic of Kazakhstan or the competent authorities of the EAEU of quantitative restrictions on imports, such as quotas, bans, permits, prior approval 
requirements, licensing requirements and other requirements or restrictions which has equivalent effect and can not be justified in accordance with the provisions of the WTO Agreement;

17) changes in the articles 4.3 and 4.4 of the $C U$ (Customs Union) Agreement on the determination of the customs value of goods imported into the customs territory of the CU on 25 January, 2008 to ensure compliance with the provisions of the WTO Agreement on Implementation of Article VII of the GATT;

18) the implementation of measures under the rules of origin of goods, whether if they accepted by Kazakhstan or the competent authorities of the EAEU in accordance with the provisions of the WTO Agreement on Rules of Origin and the reflection of interim rules of Annex II to this Agreement, including the provision of transparency, the right to appeal and notifications to the WTO Committee on rules of origin;

19) cancellation of the decision of the Government of the Republic of Kazakhstan from 14 September, 2011 №1055 «On the entering of protective measures in respect of the importation of certain types of confectionery products»;

20) compliance with WTO requirements in the application of anti-dumping, countervailing and safeguard measures in Kazakhstan, both from the part of the competent authority of Kazakhstan, and the competent authority of the EAEU; provide access to all non-confidential information relating to trade protection measures; the ability to make requests for a review of trade defense measures;

21) the performance of their concessions and commitments on the rates setting in Part V of the List of concessions and commitments on goods of Kazakhstan; bringing Kazakhstan's rates in line with the lower rates of the Russian Federation in respect of a number of goods, if the EAEU's competent authorities decide to unify export duties on these tariff lines [2].

Totally the Republic of Kazakhstan has assumed obligations under the 118 paragraphs of the Report.

At the same time the basic conditions of $\mathrm{Ka}$ zakhstan's accession to the WTO is tariff commitments on a number of commodity positions - List of exemptions, the import rate of which in the conditions of WTO lower from the existing customs duties in the CCT EAEU [3].

Obligations of the Republic of Kazakhstan on the Protocol about accession should not contrary to the obligations under the EAEU activities. For this purpose and to combine Kazakhstan's membership in both associations, members of the Eurasian Union have agreed to give Kazakhstan a special customs status. Astana pledged to prevent re-export to other countries EAEU those products which imported at lower import duties. By Council of the Eurasian Economic Commission EAEU was adopted Protocol «On some issues of import and circulation of goods in the customs territory of the Eurasian Economic Union» which regulates the entry and movement of the goods on the territory of the EAEU, which, according to the obligations under the WTO will be imported to Kazakhstan for reduced customs duties and entered into force on 11 January 2016.

The aforementioned Protocol establishes that the goods that will be imported to Kazakhstan on reduced customs duties are only intended for its domestic market. If such goods will be shipped to other countries of EAEU, the importer when imported into Kazakhstan must pay import duties at the rate of the CCT EAEU. Because the level of tariffs on a range of products is much higher than tariff rates, which are set in the WTO for Kazakhstan [4].

In accordance with the signed documents, Republic of Kazakhstan take obligations itself not to allow the export of goods that are in the List of exemptions in the territory of other countries of the Union, only in the case of reduced import customs duties.

Import of goods included in the List of exemptions, on the territory of the Republic of Kazakhstan shall be carried out by the WTO rates, but without the right to export from Kazakhstan or at the rates of CTT EAEU with a purpose of their further implementation in the member-states of the Union.

In this regard, during the importation of goods in Kazakhstan after 1 December, 2015 taxpayers need to meet the following requirements: 1) The goods imported into the Republic of Kazakhstan on WTO rates from the List of exceptions are prohibited for export and handling outside the Republic of Kazakhstan; 2) The goods imported into the Republic of Kazakhstan at the rates of CTT EAEU, during the export to the customs territory of the EAEU should be accompanied by a copy of the customs declarations and electronic invoices; 3 ) In case of export of goods manufactured in the Republic of Kazakhstan to the EAEU member-states, if the good of this group is in the List of exemptions, providing with a certificate is necessary [5].

This approach will enable Kazakhstan to fully fulfill the obligation of the WTO in terms of tariff liberalization and the level of tariff protection for entrepreneurs from other countries of the Union will not decrease. It does not create significant additional burdens for the suppliers. 
Thus, goods imported at the rate of duties, setting for EAEU products may circulate freely on the common Union market. Reduced rates of duties apply only to products intended for the market of Kazakhstan and they can not freely available to the markets of other countries.

\section{Литература}

1 Мырзахметова А.М. ВТО и внешняя торговля Казахстана: учебное пособие. - Алматы: Зан әдебиеті, 2010. - 146 с.

2 Доклад Рабочей группы по присоединению Республики Казахстан к ВТО // http://online.zakon.kz/m/Document/?doc $\mathrm{id}=35955627$

3 Соков К. Как Казахстан совместит членство в ВТО и ЕАЭС// http://www.ritmeurasia.org/news--2016-02-16--kak-kazahstan-sovmestit-chlenstvo-v-vto-i-eaes-21928

4 Казахстан-2015: ВТО и ЕАЭС: серьезных противоречий возникнуть не должно // Информационно-аналитический центр / http://ia-centr.ru/expert/21785/

5 Предпринимателям об условиях обращения товаров в рамках ВТО и ЕАЭС //Официальный интернет-ресурс Комитета государственных доходов Министерства финансов Республики Казахстан /http://kgd.gov.kz/en

\section{References}

1 Myrzakhmetova A.M. VTO I vneshnyaya torgovlia Kazakhstana: Uchebnoe posobie. - Almaty: Zan adebieti, 2010. - 146 s.

2 Report of the Working group on accession of the Republic of Kazakhstan to the WTO / http://online.zakon.kz/m/ Document $/$ doc id $=35955627$

3 Sokov K. Как Kazakhstan sovmestit chlenstvo v VTO I EAES // http://www.ritmeurasia.org/news--2016-02-16--kak-kazahstan-sovmestit-chlenstvo-v-vto-i-eaes-21928

4 Kazakhstan-2015: VTO i EAES: ser`eznykh protivorechiy vozniknut' ne dolzhno // information-analitical center / http:// ia-centr.ru/expert/21785/

5 Predprinimatelyam ob usloviyah obraweniya tovarov v ramkakh VTO I EAES //The official website of State revenue committee Ministry of Finance of the Republic of Kazakhstan/ http://kgd.gov.kz/en 
Законы, которые не равны для всех, возвращают вспять к правам и привилегиям.

Ханна Арендт 